\title{
A pandemic year and the offense to the younger generations. Suggestions and hypotheses Michele Corsi*
}

\begin{abstract}
To summarize this article with a single expression, we could enclose it in a lack, which has been widely argued on all its pages: the programming one. Moreover, there was a lack of planning and ability to predict for many institutions and most of the citizens.

Or, still, there was often a failure to prevent, in order to remedy instead, and not always adequately.

With a particular reference to Italy on these pages.

The above-mentioned four limits or wounds are particularly serious for our country in this pandemic year.

Furthermore, this pandemic caught everyone unprepared and inexperienced.

And, then, too many people - I am referring to the Government here - sold themselves to a lot of virologists and various mass media exponents, etc., who have frequently ended up increasing the unease of a nation, which is exhausted at a sanitary, economical and psychological level, with an excess of selfrepresentation and easy self-confidence, too.

In particular, this text makes school and university and, therefore, those who attend them, from children to young people, its focal point. They are not considered as abstract entities, but embodied people still belonging to an Italy at high speed: from the rapidly increasing poor people in the Southern Italy, which has not progressed yet and is in a great difficulty, to a middle class who, far from being as the fundamental nerve centre of the Italian productive fabric in the last century, is being overcome by pockets of poverty, misery and unemployment on the other hand.

Thus, the invitation to reopen school and university rooms, as it has happened for factories and companies for months. Obviously, in safe conditions. And with all the necessary due contextual measures. Moreover, in the desirable interpenetration between classroom teaching and distance learning for the next future, which is still to be entirely created in the Italian reality.
\end{abstract}

* Emeritus Professor in General and Social Pedagogy at the Department of Education, cultural heritage and tourism of the University of Macerata (Italy). E-mail: michele.corsi@unimc.it.

Doi: $10.3280 /$ ess 1-2021oa11433 
We have written these reflections, having in mind the psycho-social and educational conditions of the younger generations, so that an age of crisis does not become a double crisis in the way we are risking, and not for a little while, at present. With negative repercussions on them and all the times to come, whose signs are already evident, although they are mostly ignored. It is rather indispensable to translate them into opportunities for growth and life, culture and mental health.

And with an Italian socio-economic gap which is nevertheless increasing. Finally, we have in mind that the right to study for each person and everyone is the only social lift which can change the destiny of a country, Italy, and also restart its economy and employment.

Because skills are also a fundamental variable of GDP growth, such as a democracy effectively implemented and not only acted in words.

Keywords: covid-19, school, university, adolescence, youth.

First submission: 12/03/2021, accepted: 21/04/2021

Available online: $28 / 06 / 2021$

\section{Perimeters}

There are three perimeters. From the widest one to the most targeted or focal one. In a sort of three hierarchically progressive Chinese boxes (and this reference is not accidental, given the origin of this virus). Or a lower species of Russian matryoshkas.

The first one is precisely chronological and refers to time: this pandemic, this year or a little more, from February 2020 or earlier - for the truth which is gradually being revealed (Corsi, 2020) - and the historical context where these reflections are placed.

The second one is methodological. The thought expressed here is obviously a reasoning which derives from the arranged combination of a theoretical structure consolidated for decades (not to say for more) and data, which are always the results of interpretations and experiences (Besozzi, Colombo, 2014). These data are or "would be effective" (but the facts multiply according to different points of view) on the one hand and represent the most varied tones, with which we place ourselves in their regard on the other hand. Hence, the use of the term "suggestions" to immediately indicate that we do not intend to attribute to these solicitations a chrism of apodictic 
truth, if it was possible (Popper, 2009), but a motivated way to start a debate and to confront each other ${ }^{1}$. These suggestions open the way to a series of hypotheses or converge into them and represent the core business of this contribution.

It is like proceeding through a straw or a funnel and, in some way, descending, so that the third perimeter becomes the text of these two contexts or, better, the direction of these pages, which make up this article all together.

Starting from the ages taken into consideration: from pre-adolescence to youth. In particular, with reference to the social, affective, cognitive, school and university dimensions - not least at a relational and almost daily level (Carver, Scheier, Giampietro \& Iannello, 2014).

Especially in relation to two important development factors: growth (products) and sociality (process, food). Sociality as the primary nourishment for growth, as an effect, a result, but also a manifestation of the other two interconnected areas: culture, the achievement of information, which is the training viaticum, where it is well placed and founded, [Corsi, 1993; Corsi, 2016(1)]; and affectivity: from friendship to falling in love and real love (Corsi, 2003). All these fields need to have experiences, to consume them, to be considered and to expand. In practice, actions (processes) and acts (products for new achievements) to be accomplished. Therefore, sociality as a perennial transformation goal of a moving itinerary represented by socialization.

Pre-adolescence, adolescence and youth are already unstable evolutionary phases, as we write later in more details. Always and, especially, today. They are evolutionary and, therefore, already terminologically characterized by the condition of a journey ${ }^{2}$. A non-adult journey, made up of pervious and impervious up-and-downs, catching various means of locomotion; and often with unreasonable and risky hitchhiking. And, not infrequently, even catching ramshackle wagons to the point of various psychic, social and legal breakdowns; with sudden stops and returns backwards; apparently unmotivated pauses and stops, which are at times euphoric and at times depressed.

\footnotetext{
${ }^{1}$ There is notoriously no evaluative neutrality (Nagel, 1968). Just as naive realism has been widely renounced from classical psychoanalysis (for example, Freud, when he argues that it is true what they believe for his patients) to Gestalt psychology, from the most accredited philosophy of the sciences to various economic theories, to the international political debate, too (Corsi, 1980).

${ }^{2}$ So much so that one wonders whether developmental psychology still has a precise and delimited range of contents or time today. Formerly referred to as the psychology of developmental age, it was used to ascribe the first 18 years of a person's life in it until the late 1950s. This term has been gradually expanding forward starting from the 1970s. And this pandemic pathologically risks procrastinating it at present.
} 
This further terrible and dramatic precariousness represented by the current pandemic (a drama for which we will perhaps pay for several decades and generations) is being inserted into the condition of psycho-social precariousness: schools and universities which are opened/closed with an often extemporaneous, unpredictable and sudden stop and $\mathrm{go}^{3}$; the possibility to go out, to see one another, to meet: yes/no; the necessary extended times of falling in love and future love which are broken down, made difficult or reduced to a minimum and marginalized, when they are not indeed completely hindered or made impossible to be practiced.

The decline of practice, the fundamental and irreplaceable nourishment of these ages.

The fall of the meeting or, even, the confrontation, which are surely necessary in these years.

Therefore, the surrender of the project to be created, verified, validated and changed, if it is considered no longer functional or vital, shareable or not in the eyes of the others. In a time of life which is hungry to throw itself forward. And often without a net.

And in this writing I address to such ages, for whom this pandemic has meant offense and injury, with all the related (right or not) choices.

In this text, my reflections intend to be a diagnosis for prognosis and therapies ${ }^{4}$ to be achieved as soon as possible, without certainly denying the coronavirus tragedy in all its terrible aspects and even more.

But the scene was only left to virologists, who have widely occupied it, even when they disagree with each other ${ }^{5}$.

\footnotetext{
${ }^{3}$ So much so that the new Minister for Education Bianchi immediately declared that he wanted to reopen schools in total consistency with President Draghi and his agenda.

${ }^{4}$ With so many diagnoses which were abundant for the past thirty years both in pedagogy and politics, to limit ourselves to these two areas. So, for example, thanks to this article, we know everything about the Rt index, but almost nothing about the timing of vaccination in view of a herd immunity (the therapy for an "auspicious" prognosis), while waiting for the phantom "primroses" we hope that Draghi will be able to block and he can more appropriately use: for the 171 industrial disputes pending at MISE for some time, Alitalia relaunch, the revision of social buffers, etc.

${ }^{5}$ And with some virologists who often speak in the place of the Minister of National Health and should communicate their reflections and analyses to him, and not already to the country. They often want to be the centre of attention and it is annoying to say the least. And always hoping that it will not occur for them what happened to certain celebrities, when the spotlight suddenly went out. However, these virologists often said everything and the opposite of everything: from masks to vaccines, they declared they know almost nothing about this virus, but then they have an equally sudden $360^{\circ}$ competence. And, even in the face of these latest coronavirus variants, firstly they almost trivialized them, to identify the scientific solution which is able to stem them now: the lockdown. On this regard, even men and women coming from the so-called streets, without a degree in medicine or a medical specialization, could have perhaps reached this position.
} 
It is the same situation when there was only medicine, psychiatric hospitals, electro-shocks, etc. for psychiatric patients.

And pedagogy and psychology?

Psychology is mostly scarce and only therapeutically oriented: with the call or the clinic whistle to lord it.

And pedagogy is absent with street or school psychologists who entirely replace it.

Far be it from me to want to simulate a court, to identify faults and to attribute reports.

Virology has widely beaten pedagogy, because pedagogy has been asking for it for decades and, therefore, wanted it.

In summary, this has been the triumphant year for medicine and medicaments with human and social sciences being very rarely called into question or, in any case, only when it was impossible not to talk about the main depression (Stramaglia, 2018), which has increased in these recent months, or a more consistent use of psychotropic drugs than in the recent past.

On this regard, I recall an old saying: "Whoever is not sitting at the table is on the menu". Well, there have been neither these above-mentioned disciplines, nor our young people, nor school, nor even university at the table in this last year. They have been on the menu in order to "be eaten in their head", with the impossibility of being able to eat.

And someone could also add "nor even the people" in a cultural perspective which does not belong to me, because it is generic and not because it is already fundamentally democratic.

\section{From pre-adolescence to youth}

Three splendid and frightfully extraordinary ages in an intersected succession with each other: pre-adolescence, adolescence and youth (Caplan, Lebovici, 1979).

They are not in Rousseau's style, like the three consecutive carriages on the train of life.

Rather, they are established with Necker de Saussure's odd crossed histograms or in the hybridized or practicable concatenation in Fröbel's idealistic perspective. On this regard, both of these points of view will then open the way to Freudian hermeneutics.

With close reference to today's situation, the Western world and, particularly, Italy - which is the meta-text of the three perimeters I have written about, the country about which I am arguing - pre-adolescence ranges on average from 10-11 to 14-15 years old. Indeed, it includes a time span 
which extends from about the last year of primary school to the entire compulsory middle school, up to the first or the beginning of the second year of secondary school, in some geographical areas, for certain social classes or parts of them, and for more or less numerous students.

Instead, adolescence is "The Party", the gymnasium, the technical institutes (all these school grades to be reformed in a technological and multilingual era) and so on. It is the muff of life, the existential choice, the dreams and the delirium, the turning and crisis point of the second, effective and essential oppositive self-affirmation. Etymologically speaking, crisis is considered as a progressive conquest of judgment.

The call to gather the previous evolutionary phases in a harmonicdisharmonic representation of perspective synthesis, a self-representation: who I am, or I think to be and, above all, who I want to become. With whom and for what. How I want to fulfil myself. What kind of adult I aspire to be. With projects which sometimes have the time of a morning or the darkness of a night crossed by nightmares. The age of the shrimp: two steps forward and one step back, when it is okay. An identity who slowly consolidates and takes shape zigzag, when the peer group, the best friend, the tones of opposition to parents and relatives and, through them, to institutions and the prevailing or main culture are fundamental parameters and experiences, which need time and con-tact to evolve and to mature in the chiaroscuro above described. The con-tact, I repeat.

An age made up of great illusions and as many disappointments, fears and dismay, where the other people always stand out, both if they are mortifying and destructive or, on the contrary, constructive and companions, with a return to food and nourishment.

A period to which we often return with a widespread nostalgia on the way of the sunset of life, when we rather remember it with a melancholic sensation for the non-responsibility, the first strong emotions, the first kisses and disturbances and more, purified by the memory of the days of rain and hail, like an era of lightness, levity and, above all, heart, because after that, in particular, the years of mind will come.

But, in short, this is a really disturbed evolution, so that Anna Freud referred to it as a "developmental disorder" (A. Freud, 2007).

And between adolescence and adulthood: youth.

Youth can also be found as the first stage of adulthood in the past.

The years of university or the first inclusion into the world of work, after obtaining the diploma, until the late 1960 s or, at most, during the 1970 s, with regard to the years following the economic boom and the social expansion of the so-called middle class.

A sort of five-year period: from 18-19 to 23-24 years old. 
At the time working was possible. And if we mostly come back to the university dimension, after graduating, there were a lot of people who also contracted marriage and set up "their" house. In those times, cohabitation was very scarce, while accommodations were cheaply available, perhaps in the suburbs, which have now become the main centres of many large cities: from Rome to Milan.

Everything simple? Everything easy? Certainly not, but immeasurably lighter than today.

And, from a psycho-social point of view, the fog of adolescent developmental disorder was gradually lifting and clearing away, the per-son was created (Stramaglia, 2011), more or less long, summer and para- summer flirtation and falling in love left the ground to that affective-relational field once called "engagement".

A period of less suffering and greater creation, when the promises of the best parents were almost punctually fulfilled (Corsi, 2001): firstly study, secondly work and, finally, the consolidation of love choices.

Now? Or, better, until a year ago?

For decades, adolescence has been overflowing into youth like a river full of mud and alluviums, after an almost equatorial flood.

So, we wonder: when does adolescence end in a more or less recent present?

And when does youth begin?

Fifty years ago, Peter Blos (1971) had already written and argued about prolonged or protracted adolescence.

This adolescence beat youth like the dirty engine of a car and made it retreat in its rising until the age of 30 and later, because the progressive employment crisis with the consequent lack of economic autonomy opened the "stables" of social autarchy wide and put the planning of a stable affectivity in a critical position, giving life to a nomadism of more or less intense affective-relational experiences, which could be short or very short in days, hours or limited intervals. Sexism versus healthy and relaxed sexuality.

Therefore, this adolescence had been becoming stable over a duration of almost twenty years during the pre-covid period. And tomorrow? In the years to come?

On the contrary, Bettelheim (2013) had identified that adolescence as the typical one of a very small social minority in the $19^{\text {th }}$ century, only to gradually expand in the $20^{\text {th }}$ century and to become recognizable and almost widespread throughout the Western world, progressively gaining the characteristics of a homologation. In fact, in Pasolini's interpretation (1999), the difference in class and wealth between proletariat and bourgeoisie was very clear and evident before 1968, while then it gradually disappeared not 
with regard to liras or euros, but certainly for customs and choices or more or less legitimate desires, which people tempt to reach even with illicit means (because it sometimes deals with temptations), when they are not practicable. An example: drugs are taken in good neighbourhoods and suburban areas. Girls prostitute themselves for need, constraint, fun or boredom.

Therefore, adolescence stands out today with some forms of a frightening and jagged tumour growth, without limits and clear boundaries.

Keeping real adulthood silent after this adolescent magmatic lava.

Therefore, youth is also precariously inserted into adulthood in an imprudent way (nowadays, prudence is not fashionable, it is an ancient virtue), when it was laboriously reached as an intermediate stage with its myths above and below. The times of youth and maturity are confused and dispersed with less and less mature adults, a very few real adults and "young" people in their sixties and over, who are pathetic and out of time (Corsi, 2015).

\section{Growing up together among peers and the need for certainties}

I repeat that the three just described ones are ages of psychological and social disturbance.

Years ago I talked about theft in several of my writings, with reference to the crisis of the first republic and its end - a period about which history will have a lot to say with the unedifying mixture between judicial system and international political and economic-financial interests -: the theft of work, on which our mistreated Constitution is based and introduced. It seems too tight like a small jacket with all due respect to democracy and intellectual honesty and, with it, the theft of hope for younger generations.

They are desperate and unemployed, using a socio-pedagogical reading of context with respect to the text of Blos' psychoanalytic point of view.

Now, this pandemic year has operated another theft against our children, students and young people: not being able to be together, to make a group, to live the group, to meet and to gather on the streets, in bars, outside school, to talk, to tell each other, to confront each other, to touch each other, to read each other in their faces, to grasp the nuances of emotions without masks. And, instead, today everyone has masks.

Of course, it has been said that there are telephones, mobile phones, tablets and video calls.

But until a year ago wasn't the civilization of these aids criticized, invoking the return to the wall on the streets (Recalcati, 2019)? 
Didn't we speak about them and the proposing culture as pathological behaviours regarding children and young people who spent their days closed in their room in front of their computer, counting likes and virtual and extraterrestrial friends on social media?

But currently it is argued that it has not been possible to act otherwise.

Are we really sure?

Or has the easier choice been made? Certainly in a period when nothing has been simple or easy. And we did not certainly have a manual about pandemic and there was not a consolidated history of choices made in the past.

But also about this: the silence of pedagogy.

I softly remember that educating is not repressing. This has been affirmed and reiterated for at least two centuries in the history of this discipline. Rather: to allow, motivating; to prevent, discussing. After decades of permissiveness, however, here is the return to an imposed and medically justified authoritarianism, but it is not educationally argued, with the guilt widely used and flaunted to lord it, as in the worst pre-conciliar Old Catholicism when all the young people were ugly, bad and guilty of killing grandparents and parents in poor health.

But, however, organizing is not forbidding at a socio-political level.

Organizing is certainly much more tiring and difficult.

Forbidding is easier and more simplistic.

Moreover, a Neapolitan saying states that life is a bite and all depends on the flavour we want to give it.

Our teenagers and young people need to give more bites, infinite bites to life, because they do not know yet which flavour they intend to give to the days of their life. They need to try and to try again and, therefore, they need experience and time ${ }^{6}$.

Now, however, we have closed their mouth and we have made them almost silent and voiceless.

They are socially and emotionally anorexic. I will talk about their cognitive level later, but not only about it because of the mixture of their entire personality within it, with reference to school and university, starting from the social classes to which they belong and in relation to the society to come.

That is, we have taken their main food away: being together and meeting in relax, in order to grow up together as an individual.

Therefore, even the certainties: the external ones of predictability and their own internal and personal ones, with the need of a com-pany to make them

\footnotetext{
${ }^{6}$ In literature, compare Salinger's evergreen novel (2014), The Catcher in the Rye.
} 
more or less autonomously, between individual and group conflicts and their possible resolutions.

And, nevertheless, to verify those values which family had given them during infancy and childhood, in the best families where fathers and mothers are still committed to parenting [Corsi, Stramaglia, 2009; Stramaglia, 2009; Corsi, 2016 (2)], even in an age of crisis we are dealing with.

On the contrary, which certainties are there in a pandemic year of uncertainty? Society, psychology, school, etc. often sailing in some uncharted waters? A second wave: yes/no; a third wave: perhaps; the vaccines will arrive, but then they will not arrive or, in any case, be almost difficult to be delivered to us, even it is committed by a European program; vaccination will solve everything and, instead, "maybe" not with the South-African, Brazilian, English, etc. variants, with a new anxiety for each day; above all, the anxiety of not being able (fault or not, responsibility or its exact opposite, with all the intermediate nuances of the case) to prevent... let others prevent, not being able to plan even the most banal and almost daily experience at least. If this is true for adults who, in any case, have greater resources to live with precariousness and have often encountered it in their lives anyway, what about adolescents and young people?

In addition, omnipotent adolescents (Coleman, 2015). Or does psychology no longer count for anything during the covid time?

Or the young people in Gino Paoli's song about four friends at the bar. Destroying, dreaming, rebuilding, and then getting old... they are resigned to what is possible and practicable. But it is not pessimism, it is a principle of reality.

None of this. Impotence is rather slammed in their face.

So, our temporal heirs have been more lonely and terribly lonely since a year. They are lonely with their fears, nightmares and delusions, with a hungry body (Lavanchy, 1994) and, equally, hungry heart and mind, without containers and restrictions, with an intermittent sociability. They do not know if they are in yellow or orange or, worse, red zone in the following day and if they are able to meet their boyfriend or girlfriend, their friends or group belonging to another municipality. They are deprived of associative rites, confrontations and reference points. And I could go on indefinitely.

I think young people and even adults - therefore, tomorrow's society in a few subsequent decades - will personally pay for all of it.

Growing up and living with instability during the time of instability is a double curse. Speaking well in an age when we need to speak well and to feel good.

Thus, no wonder if how they can, they gather together and cause confusion: yellow zone and so on. 
It is like a ball held underwater which shoots upwards when you free it ${ }^{7}$.

It is like when parents go out or on vacation, and their children have the opportunity to stay at home. We all did it: friends, invitations, parties and whatever is cheerful and noisy.

Now, they say: - Oh no! One must be responsible -. They must be 40 or 50 at the age of 15-20 years old. If practiced, this monstrosity would make the flesh creep.

And then, down with hypocrisy, which 40-50 year-old people are we talking about?

Today's people, at least in large numbers?

Should I proceed with today's socio-behavioural analyses and descriptions, or can I stop?

\section{Distance learning and the right to study}

Anyone who is sufficiently familiar with my thinking and my writings knows very well that teaching does not mean only educating - taking for granted and universally recognized that schools and universities are teaching places -.

But both teaching and being teachers mean educating in a combined conjunction with each other (Scheffler, 1972). They have the same commitment, and not the detriment of the other one.

Moreover, there is another refrain of mine: - now, a certain prevailing dull, sickly, not adequately founded or epistemologically rigorous, selfcongratulatory didacticism, especially in school (while OECD rankings will also want to say something about the bad school positioning in Europe ${ }^{8}$, or is it just students and their families' fault?), has almost banished most of the interpersonal relationship for the pedagogical-educational activities to the loft for years in the late $19^{\text {th }}$ century or the first half of the $20^{\text {th }}$ century. Or it has done its best at least in the last thirty years; I always refer to Italy, even if what happens or happened in the rest of the Western world in relation to the educational eclipse is not very different.

\footnotetext{
${ }^{7}$ A bit like the situation for Draghi Government Ministers, who were happily assembled slapping each other on their shoulders during the transfer from the Quirinale banqueting hall to the cuirassiers' room for the ritual photo, after the oath and the spontaneous human anxiety for the appointment or the confirmation obtained on February $13^{\text {th }}, 2021$.

${ }^{8}$ These rankings define both Italian schools and universities as inferior. This opinion also expanded to the international rankings, where (many) Asian universities are virtuously growing by now, while our country annually loses several positions, instead.
} 
Even starting from the widespread diffusion of the television, then we also witnessed another progressively increasing phenomenon with the advent and the subsequent gigantic expansion of the media towards the 1970s: the flourishing and the arrival of distance learning, starting from the Anglo-Saxon world and, from here, to countries with large areas and big logistical difficulties, such as the very advanced Finland, or Asia, with the undeveloped Mongolia characterized by nomadic and pastoral settlements, or the Australian universities chosen by a lot of students coming from the Southeastern Asia.

We have four important reflections to be noted, though.

Firstly, school distance learning in Finland is not just education: it is a $360^{\circ}$ teaching or, at least, there is a significant care on this regard - only to consider this paradigmatic example - .

Secondly, and it is no small thing, in those countries there has been a whole course of training and technological progress, which is almost at the year zero or still laughable in Italy. In those countries, teachers were trained for their subject and not obliged on this regard.

Thirdly: most of this proposal, especially in the USA or Western Europe, mainly concerned higher education and, above all, university. So, they are people already "sated" and certainly not people less "sated", such as those who live in the ages of growth, as my Master claimed in the 1960s (De Giacinto, 1966).

And I conclude with a fourth further reflection, which is by no means trivial and particularly concerning the university institution: the possibility of choosing distance learning. Users are addressed to an online university rather than matriculating in a face-to-face one for their well thought-out and personal considerations. They choose the best distance universities in the world which, through a fully interactive teaching and a whole series of highlevel services for their students, are certainly not limited to video-recorded lessons and that's it, but they assume the responsibility for the entire complexity of their learners.

Instead, there is no discretion for schools and universities in Italy during the covid emergence: just take it. In a period in which we certainly do not regret they would have been said: - Obey and keep quiet.

In addition, this has often happened overnight since the first closure at the end of February-May 2020 and, even after that, it often keeps on happening almost frequently overnight and suddenly, with all due respect to family organization.

Therefore, on such a complex regard, everyone is often unaware both of the country and its goals - non-goals achieved in this field with a deliberate mystification, and that's an euphemism, when we were not filled with an 
annoying and obscene proto-romantic molasses. And I keep quiet because I could go on with many other examples, not only concerning distance learning.

Nor should it be overlooked that the university system has always neglected its students' education; mostly with the advent of mass postdiploma education and the liberalization of curricula. University is considered as a single container of classroom conferences-lectures mostly addressed to the front rows with most of the professors who are motionless and embalmed on their chairs like Egyptian mummies. Woe betide if they stand up. And, in this way, the exams, the ongoing (scarce and not very widespread) marking and ex post etc. Universities are cold bodies wrapped in rigor mortis.

But let's go back to school.

Then we will resume all the happy combination to be created between distance learning and classroom teaching, both for school and university environment.

And, now, let's wonder what school is.

A large container which offers experiences and contains.

Experiences of culture, sociability and affective relationships.

And it contains them with its rules and opportunities.

Restriction rules. And God only knows how much they are necessary during pre-adolescence and adolescence.

For example, the possibility of socializing, confronting, loving some teachers and caricaturing others needs to keep on growing up in some decision-making dimensions and improving the identification processes.

It is an extraordinary gym where you can exercise for life.

But all the gyms were closed. Even the school one.

At the same time, good functioning orders were also given, only to be denied and trashed the next day, in an immeasurable triumph of improvisation and total shifts, as for the situation of restaurants etc.

So much so that all our students were on vacation at home but, after the euphoria of ten-eleven months ago, they woke up from this poisoned gift and began to complain that they want to go back to school. They were more highminded than adults and rulers on duty.

\footnotetext{
${ }^{9}$ Why did they want a finally democratic university or did they rather make it as a sort of gymnasium once it was evident that it was difficult to find a job with a diploma mostly in the following years? That is a typical habit of the worst Italian politics, after the years of the great ethical post-war reconstruction: instead of solving problems, they postponed them. And, in the meantime, we survived and made a living. Not bad if the country slowly ran the risk of collapsing. It was not the fault of that generation or those rulers, but those who would have later picked up that poisonous and toxic apple.
} 
They began to feel the emptiness of their human and training possibility for global growth, existential opportunity, education, self-education and coeducation, complete reciprocal exchanges, con-tact with each other, con-tact with culture, which has finally and positively rediscovered.

Culture is not intended as superficial factual knowledge, dates and galleries of madmen, etc. (as in a few secondary school lessons in history of philosophy), but as various cultures, learning, dialogue and confrontation with history and stories.

This is not everyone's consideration, but the people who mostly pay attention to their future destiny certainly think so.

But I come back to the great mystification of distance learning in Italy in the last year.

It seemed that teachers were well trained on the subject but, on the contrary, their level is very scarce and limited.

Schools have also been described technologically equipped: it is false for at least one third of the country. For example, a distance learning, which is near the city where I live, has been solved giving homework through the electronic register for months.

Nevertheless, we have imagined (with an imagination bordering on disease if not beyond) a country with wealthy families in possession of several equipped and well-functioning computers and cameras. We have also imagined sufficiently capacious accommodations where children of different ages could safely and positively have distance learning with the help of some parents who are maybe in smart working. And not the dramatic reality of a consistent part in Italy where the network does not arrive or arrives badly: $39 \%$ of the country. Not to mention the houses located in an authentic basement, $40 \mathrm{sqm}$ accommodations for $4-5$ people, a South which is not certainly the South Tyrol. And I could go on indefinitely with a whole series of other references.

Or even I suspect that the right to study has been confused, overlapped and badly amalgamated with the family organization.

For example: who does not remember the babysitter bonus, which could also be used by grandparents (Stramaglia, 2013), when both parents had to go to work and the entire school sector was closed?

Now, we do not talk about it anymore.

For different and more recent choices.

In fact, it was decided that it was possible to go back to school from the entire cycle of primary school to the first class of the middle school in a large part of our country for this school year 2020-2021.

Perhaps, we hope that children from 12 to 14 years old could stay alone at home without checks and custody, while their parents were at work. 
Someone should explain to me where the pedagogical ratio for this choice is.

I do not know why childhood and early pre-adolescence need school, education, restriction and socialization, while the subsequent turbulent flourishing of the latter age can do without them.

According to public opinion, do children in the second and third class of the middle school make more crossroads among themselves, after lessons, and does the virus spread?

Is it only sure, because primary school children are usually taken to school by their parents' almost medically safe cars, while from 12-13 years old onwards: away with parents, and everyone by public transport?

On this last regard, how can we keep silent about the government idleness in relation to transport, for which nothing has been done?

Or does everyone go to school by those charming and radical-chic push scooters?

I forgot: the use of wheeled desks as well. Moreover, they are not fully delivered in the middle of this school year 2020-2021 yet.

It must be remembered - These wheeled desks are not magic wands, being able to widen the capacity of classrooms, which are often scarce for dimension and reduced for the possibility of movement.

Why, then, wasn't it thought about drawing up agreements with the private school world to have more containers and areas available?

This was done in the past when earthquakes occurred. Has this pandemic perhaps anything less than an earthquake ${ }^{10}$ ?

After all, double shifts for both parents have been currently discarded at work (with the hope it lasts and a frightfully growing female unemployment).

Of course, double shifts have been the rule for several years, immediately after World War II. I remember them well. I lived them in "Fratelli Bandiera" primary school in Rome, which I attended in the mid-1950s. But at the time $80 \%$ and more women or mothers were housewives.

In other words, the product "school" was once again badly operated, without appropriately taking care of the processes: transport and areas.

Moreover, schools are adequately sanitized with school headmasters and teachers who had worked well on this regard, before reopening the current school year. A useless work ${ }^{11}$.

\footnotetext{
${ }^{10}$ So, the above-mentioned Minister Bianchi properly referred to earthquake when he said that schools must be reopened, as it was usually done after an earthquake as a sign of life, recovery, hope, growth and future.

${ }^{11}$ Like the sudden non-reopening of ski resorts, hotels and mountain huts etc., on February $14^{\text {th }}, 2021$, four hours after their planned and announced start-up. It was another useless and expensive work, so much so that compensation is now being requested and not only financings.
} 
And, then, another oddity: the first year of secondary school in classroom and the following years not.

Beyond the tale they told us about letting them breathe their new school choice, the other suspicion concerns a mere marketing action: not to lose students enrolled in gymnasiums and technical institutes and not to consequently create further unemployment in the teaching staff.

Wouldn't secondary school students of the final year also need to go back to the classroom in view of their secondary school diploma and university choice?

The cheap economy and a certain prevailing medicine won ${ }^{12}$.

Pedagogy was kept silent again. It is lost in its literature and is not even found in the best and the most well-stocked bookshops in the country. And I do not think that everything can be solved with an a-scientific justification of conspiracy against this discipline ${ }^{13}$.

The choices made by public and private state universities were not different.

Distance learning by edict in universities (and there are many) which have always spurned and rejected it.

They have some equipment often scraped together at the last hour, videolessons and professors who are mostly untrained to use these aids. And I am not even talking about competence (this word is too demanding and out of place here) in relation to this specific and special teaching method.

In my opinion, this was also a marketing or a survival decision, as for schools.

Face-to-face lessons have been possible and made practicable only for the first years of the three-year and master's degrees. While the students, who have been already matriculated for some time, have distance learning.

They always have a few computers, which are actually suitable, good numbers of defective cameras and euphemistically small accommodations.

On the contrary, all the students - except for those who matriculated in online universities by free choice - need to breathe school and university air.

${ }^{12}$ Like journalists: they have been too many in this last year, with an excess of visibility and an often annoying self-representation. They have been sometimes more ideologized than the most burning and revolutionary party men. While the country rather needs facts and silence than bombastic proclamations which are disavowed the next day, euphemistically low narcissisms or worse, that is, pentacostal interpretations of history or individual events.

${ }^{13}$ So, we could only greet with pleasure President Draghi's double claim for the role of education in his programmatic speech to Parliament on February $17^{\text {th }}, 2021$. An economist rebuked pedagogy. Instead, this year pedagogy has been predominantly silent about adolescents and young people, schools, universities and teaching, which are, or would be, their main fields of intervention and writing, too, except for those interventions which have been sometimes too "biased". 
Particularly, in relation to university, it is necessary to experience libraries, to confront each other, to learn from each other, to contaminate each other as soon as possible.

However, as far as schools and universities laboriously could, in this last year they have no longer been those social lifts, which are so necessary and, mostly, still celebrated only or largely in words and with evidently scarce and not conclusive measures in our country.

The right to study was offended and marginalized.

This is valid especially for those pupils belonging to poor or culturally deprived families.

For example, the Italian university is not only attended by the uppermiddle class, who often goes to study abroad and has bookcases and volumes within their own house.

On the contrary, in many Italian families, there are only timed and used schoolbooks, which are resold to buy other books for the following years. And newspapers are very rare avis. And I stop here.

Therefore, social class and wealth disparities have inevitably increased or, rather, have emerged to be crystallized and to become things: Sartre's hell (2014).

The last question - Why was it possible to come back to work in the factories, but not to come back to school?

Are working adults more responsible?

Does it happen only because companies directly and immediately contribute to GDP creation, while training concerns the future and it is not therefore a today's matter?

But what has our country still done for young people's education, at least in these last forty years, when we were talking and writing about the crisis of education everywhere, including at the Italian Bishops' Conference?

I close this item saying that in this last year I have personally and progressively realized a lower preparation in the exams for students who had kitchens or bedrooms with a few dozens of books as background, when I have watched them on the computer.

These students of ours should be treated the most, because they are our future.

Before making a proposal of due interpenetration between distance learning and classroom teaching, there is a last observation for a future I hope it is near, but it is all to be seriously created.

I immediately declare that I have not tackled the very important and strategic chapter about pupils with disabilities from kindergarten to university either: this is a question of great civilization and authentic democracy. I did not do it, because I should have created another article, instead of writing a 
paragraph, nevertheless I am aware that it will be the central and thematic focus of this ES\&S issue.

Then, what is the proposal?

In the current mass-media era, when everyone and, in particular, young people - and, before them, adolescents, pre-adolescents, children, etc. -, are real digital natives (Ferri, 2011), teaching voices and ways must be multiplied to compensate and to interpenetrate each other.

Classroom teaching needs to modernize. No longer just face-to-face lessons, blackboards, chalks and photocopies.

And a well created and refined distance learning must be able to enter all the schools and universities.

For example, this latter institution must create an extraordinary mix of actual effective right to study for those who attend or cannot attend lectures, in order to really reach our students' heads, habits and skills today.

But it is necessary to train teachers, to master the complexity of these aids and to know how to really manage them, to have specific aids for students with disabilities, to put in place a new methodology for the transmission of knowledge, and so on.

However, it takes time and not improvisation. But it does not take an eternal time, waiting everything falls into oblivion, once the pandemic is over.

Therefore, it is necessary to act in favour of a working alliance between online universities and their didactic research and face-to-face universities and their heuristic courses.

It needs a cultural unity, such as the national unity government born in these days. This is the last chance for our country before sinking into the abyss.

Therefore, balance and competence are needed; and the best energies must be put together, because they are always useful, especially today.

Balance: a word and a way of being I particularly love.

\section{To conclude: a socio-cultural regression, a youth emergency and a new reconstruction of the country}

I think I was clear that schools and universities are crucial, fundamental and founding areas for the growth of the country, nevertheless in GDP terms: a public debt reduction, an implemented and not acted democracy, a social equity, a reduction of the gap, a real overcoming of many human and economic peripheries of our nation, a present which must be carefully planned in view of a healthier and more democratic future, crossed by a greater wealth. 
Otherwise, many references to the values and the attentions abovementioned risk being only configured as warnings or mere verbal pronouncements, which aren't then translated into real change actions all over the place, on both sides of the Tiber, including the Vatican.

I repeat we have a debt, which has dramatically increased in this last year, while economic growth has frightfully regressed.

So much so that it represents a real alarm for the European Union, who wisely came to help us with the 209 billion Recovery Fund, because the Italian crisis risked and risks representing a non-trivial criticality for other European economies with heavy repercussions on this regard and their business structures, other industries, etc.

More closely taking into account our nation, the necessary stopgap provision for blocking dismissals and the related use of unemployment benefits will not be able to last long or to solve these age-old dramatic problems in Italy.

This is especially with regard to the poorer classes, the workers (many of them are close to unemployment), the elderly who do not know how to live etc.

A far-sighted and decisive advancement is rather needed: it must not exclusively operate for subsidies and financings - as it is happening too often at present -, but for provisions and strategies which create jobs, increase employment for young people and women and are able to promote a greater widespread economic and social well-being as much as possible.

It must happen overnight, not too far away, especially with regard to our "heirs": children and young people, in order not to leave them a selfish pile of rubble, which already abounds a lot.

Someone could say that this is politics, but where is pedagogy?

Well, I think that pedagogy and politics, education and education in politics refer to each other; one is the premise and the consequence of the other one. Politics must favour and implement a greater growth for a country and the people who live there. Just as education - the theoretical-practical object of pedagogy - should be able to nourish the ambition to improve politics, in order to interpenetrate each other, as in the best centuries of human history.

Moreover, education cannot ignore the political context and its decisions for the future to be created, in order to write the best pedagogical text, or otherwise, as it happens too often, it gives life to a badly made and schlocky plot.

Therefore, we are very far from a metaphysical and non-embodied pedagogy in this perspective, so as to support the "physical" science of opportunities and practicability. 
Otherwise, we would not write today's pedagogy for the future we would like for the benefit of a magnificent and progressive human destiny, but a rhetorical speech, which is not contextualized and is more or less valid for all the seasons and, therefore, none in particular.

We must be as Saint Philippe Romolo Neri said: "be good if you can" and, currently, it could perhaps be good for the heart and the simplest and the most immediate emotions, thanks to the progress of all the sciences, including psychology, but not for the mind, the pockets and the real life.

This synergy between pedagogy and education in politics was one of the aspects of a research doctorate for both Luisa Santelli and myself at the universities of Bari and Macerata about fifteen years ago. My very valid pupil and heir to the chair I left for retirement two years ago, Massimiliano Stramaglia $^{14}$, came out from this very happy experience.

Let's come back to schools and universities in this last pandemic year.

Their closure, the sporadic didactic, classroom teaching and (mainly) distance learning, $50 \%$ of the lessons in the classroom today and $50 \%$ online have stopped the country and most of our students' overall maturation, at least, with the exception of the luckiest or, perhaps, the wealthiest pupils; without betting too much on it.

But, a huge number of pre-adolescents, adolescents and young people: those who have less personal, cultural and economic resources, have undoubtedly lost a lot.

A greater ignorance spread and was not scarce before either. For example, many university students ignore the 1968 phenomenon in Italy and the Western world or the fall of the Berlin Wall. Two significant facts and symbols.

Therefore, if we have poor people who are economically poorer and poorer and lined up for charitable meals, an agonizing evidence at present, nevertheless we are witnessing poor people who are also culturally and intellectually poorer and poorer. They are deprived of the fundamental notions, the necessary critical spirit and that wealth of information, which is useful to rule themselves, their history to be still created and defined and, through them, the future history.

\footnotetext{
${ }^{14}$ A very strong common thread for continuity connects us. Although we are children of different times, both of us love contemporaneity, we serve it and we have introduced it in our studies and work. Perhaps, I was the first Catholic pedagogist to take care of the transition from the singular term of family to the plural, complex, evident and indelible term of families or to make the political reading a necessary magnifying lens to understand and to relaunch school, family and social policies in more recent times. And he opened the doors of our local pedagogy to an internationally widespread trend with his research on mass-media, icons of modernity and pop cultures, etc., so as to be mentioned abroad and in volumes belonging to other scientificdisciplinary fields.
} 
This pocket of ignorance will make our nation go back or, in any case, will not throw it forward.

Instead, it is necessary to make an effort to increase skills, including the digital ones. All and none excluded.

The future of a country is based and "risks" on the growth of skills.

It particularly deals with the skills of the younger generations who will inhabit the future of a nation, which must be better than today's.

We have discussed about cognitive skills in the last few passages of this article.

There are social, affective and relational skills and, nevertheless, technical and IT skills elsewhere in this writing as well.

It is necessary to play a winning symphony, white keys and black keys, treble clef and bass clef on this entire keyboard.

We must observe especially our children, from their birth to their entry into adulthood.

This is why it is necessary to create different and innovative schools and universities, "with the lights always on".

It is essential to economically, culturally, educationally and didactically invest in them.

It is necessary to give rise to a different and better training for learners as well as teachers.

This is important if we do not want to further divide our country from north to south and the social classes among them. Then, it would be the premise of a social unease which is difficult to solve and a very bad prophecy.

As already mentioned, pre-adolescent, adolescent and youth emergency is, finally, the sub-text of that school-university text about which we have discussed so far - or, in any case, a fundamental sub-text, besides a different teaching training -. And, for at least ten years, it has been indicated to us as an area where we must intervene with an effectively therapeutic strength and ability, because we do not know what to do with more or less complete diagnoses or relatively poor prognoses if the processes do not proceed and the products are not created.

Moreover, it is no coincidence that the Recovery Plan has the title "Next Generation You", in line with what has been argued so far.

And a part of this fund should be allocated to education in general and, especially, higher education for their modernization.

Skills cannot be cast off or set aside. One is not worth the other one. Future cannot be abandoned, in order to keep on wandering on a dark night when all the cows are black. 
I close saying that we have had to appeal to the most competent Italian person we have in recent days: Mario Draghi, to take us out of many fords where our country has got bogged down.

So, I end with a wish, almost a dream, in an article where I hope I have moved in the light of a principle of reality, instead.

I would like the future of our country to be inhabited by a lot of people like Mario Draghi. Each one in their own way.

We must start from here for the overall reconstruction of the country: from schools and universities - social lifts of the only revolution I love: culture and progress, and not blood -, from the development of educational, relational and personal skills as well as great specific and well-founded cultural skills.

We must also do it quickly, because time is up and recreation is over (Bottani, 1986). Indeed, this should have ended almost forty years ago according to the illustrious Swiss scholar. But in Italy we love to especially extend the time of what is worth less.

\section{References}

Bettelheim B. (2013). Un genitore quasi perfetto. Milan: Feltrinelli.

Besozzi E. \& Colombo M. (2014). Metodologia della ricerca sociale nei contesti socio-educativi. Milan: Guerini Scientifica.

Blos P. (1971). L'adolescenza. Una interpretazione psicoanalitica. Milan: FrancoAngeli.

Bottani N. (1986). La ricreazione è finita: Dibattito sulla qualità dell'istruzione. Bologna: il Mulino.

Caplan G. \& Lebovici S. (1979). Problemi psicosociali dell'adolescenza. Turin: Bollati Boringhieri.

Carver C. S., Scheier M. F., Giampietro M. \& Iannello P. (2014). Psicologia della personalità. Prospettive teoriche, strumenti e contesti applicati. Turin: Pearson.

Coleman J. (2015). Perché non mi parli? Il conflitto tra genitori e figli adolescenti. Milan: Raffaello Cortina.

Corsi M. (1980). Il ruolo dello psicologo nel consultorio familiare. In: C. G. Vella, Gli operatori dei consultori familiari. Rome: Città Nuova Editrice.

Corsi M. (1993). Governare il cambiamento. Le risorse della scuola italiana. Milan: Vita e Pensiero.

Corsi M. (2001). Educazione e promessa. In: Giambalvo E., Cinquant'anni di personalismo critico. Tra metafisica e ricerca pedagogica. Palermo: Edizioni della Fondazione Nazionale "Vito Fazio-Allmayer".

Corsi M. (2003). Il coraggio di educare. Il valore della testimonianza. Milan: Vita e Pensiero.

Corsi M. \& Stramaglia M. (2009). Dentro la famiglia. Pedagogia delle relazioni educative familiari. Rome: Armando. 
Corsi M. (2015). The Adults are the Problem of the Young. Pedagogical Itineraries and educational Emergencies. MeTis, 9: 16-25.

Corsi M. (2016 (1)). Culture will defeat Violence. Pedagogia oggi, 1: 15-26.

Corsi M. (2016 (2)). La bottega dei genitori. Di tutto e di più sui nostri figli. Milan: FrancoAngeli.

Corsi M. (2020). Il tempo sospeso. L'Italia dopo il coronavirus. Milan: FrancoAngeli.

De Giacinto S. (1966). La struttura dell'insegnamento. Neaples: Morano.

Ferri P. (2011). Nativi digitali. Milan: Bruno Mondadori.

Freud A. (2007). Normalità e patologia del bambino. Valutazione dello sviluppo. Milan: Feltrinelli.

Lavanchy P. (1994). Il corpo in fame. Anoressia e bulimia: riflessioni sui disordini alimentari. Milan: Rizzoli.

Nagel E. (1968). La struttura della scienza. Problemi di logica nella spiegazione scientifica. Milan: Feltrinelli.

Pasolini (1999). Scritti corsari [1973-1975]. In: Sisti W. \& De Laude S., Saggi sulla politica e sulla società. Milan: Mondadori.

Popper K. (2009). Congetture e confutazioni. Lo sviluppo della conoscenza scientifica. Bologna: il Mulino.

Recalcati M. (2019). Le nuove melanconie. Destini del desiderio nel tempo ipermoderno. Milan: Raffaello Cortina.

Salinger J. D. (2014). Il giovane Holden. Turin: Einaudi.

Sartre J.-P. (2014). L'essere e il nulla. Milan: Il Saggiatore.

Scheffler I. (1972). Il linguaggio della pedagogia. Brescia: La Scuola.

Stramaglia M. (2009). I nuovi padri. Per una pedagogia della tenerezza. Macerata: EUM.

Stramaglia M. (2011). Amore è musica. Gli adolescenti e il mondo dello spettacolo. Turin: SEI.

Stramaglia M. (2013). Una madre in più. La nonna materna, l'educazione e la cura dei nipoti. Milan: FrancoAngeli.

Stramaglia M. \& Rodrigues M. B. (2018). Educare la depressione. La scrittura, la lettura e la parola come pratiche di cura. Bergamo: Junior. 